\title{
DEMOCRATIC MODERNIZATION AND POLITICAL CULTURE
}

\section{Baklanova N. M.}

\section{INTRODUCTION}

The problem of determining the role of the state in social life and the value orientations of the demos as a participant of political transformations are attracting increasing interest of political scientists. Despite different points of view regarding the essence of the state prevailing in various historical periods, the recognition of the role of the main political institution has remained unchanged. Ukrainian society like other states of Central and Eastern Europe, is at the epicenter of a global transformational dynamics. The democratic transformations in these countries marked the beginning of a new stage in the processes of democratization, the third one in the world political history (according to S. Huntington).

In states, the process of democratization is specific, but political science, based on comparative analysis, has elucidated a number of foreign policy factors on which its stability depends.

One of these factors that can directly contribute to or impede democratic political development is political culture. Using the specific historical method, the essence of understanding political culture as organically connected stereotypes of political consciousness and behavior in the society, as well as models of the functioning of political institutions and political regime as an important characteristic of the political system, were revealed. It was proved that there is some difference in the political culture of social subjects, which are driving forces at different stages of social development: at the stage of transition to democracy, it is the level of political culture of elites which is crucial and on which the form and effectiveness of political institutions' functioning depends directly; at the stage of establishing democracy, when new political institutions and procedures are introduced into the practice of everyday life, the level and significance of the political culture of masses increases.

Democratic political culture is a culture of civil society where the pluralism of interests of a wide variety of social and political forces dominates. The formation of a democratic political culture of masses is always the result of the effective functioning of democratic political institutions, and this takes time.

It is only a developed civil society where culture that corresponds to a democratic regime can be formed. Pluralism of political ideas implies the right of citizens to unite in political parties, public organizations, means their free 
and equal activity within the framework of a multi-party political system, the opportunity to take part in the political life of the country, and, thus, influence the activities of government and administration using the existing legal mechanism. And this, in fact, is a transition from a party-state system to a multi-party system and separation of powers. The political culture of Ukraine is largely determined by the history of its development. For many years at the crossroads of Western and Eastern political cultures, the political culture of the Ukrainian people and their mentality have been formed as a combination of various cultural components with a predominance of Western components.

The level of the mass consciousness of the Ukrainian society is characterized by inconsistency, segmentation, ideological and political diversity.

Ideas, orientations, moods, stereotypes of thinking and behavior cultivated by the Soviet regime have still existed in the society. And disappointment in the realities of the state authorities of nowadays, the social standard of living give rise to passivity, inertia, irresponsibility, moral primitivism. Along with the destruction of traditional structures and mechanisms of social integration, ambivalence becomes the dominant type of social orientation. At the present stage, the Ukrainian society is in urgent need not only to develop, but also to introduce a clear concept of integrating ideology which will contribute to national consolidation, the development of civil society, and hence a democratic political culture. It is well-known that the mechanisms of the formation and development of civil society in modern Ukraine are the national mentality and national-political activity, thereby affecting the level of political culture.

\section{Theoretical concept of political culture}

Since Antiquity, almost all scholars have addressed this issue to some extent in their works. Focusing on various aspects of the essence of the state, the authors understood in a different way the role and influence of this political institution on the life of society, it was Aristotle who perceived the state as a large patriarchal family ${ }^{1}$; the state within the framework of a religious worldview was considered as an earthly institution of power established by $\mathrm{God}^{2}$; or the state was seen as the result of a "social contract" to ensure the rights and freedoms of citizens ${ }^{3}$. At the same time, despite different points of view regarding the essence of the state prevailing in various historical periods, the recognition of the state's role as the main political institution has remained unchanged. Today, the state has still played a leading

${ }^{1}$ Аристотель. Сочинения: В 4 т. Т. 4 / [пер. с древнегреч.; общ. ред. А. И. Доватура]. М.: Мысль, 1983. С. 376-644.

${ }^{2}$ Аквинский Ф. Сочинения / [пер. А. Апполонова]. М.: Ленанд, 2015. 242 с. 1990. $524 \mathrm{c}$.

${ }^{3}$ Гегель Г. Философия права: Пер. с нем. / [ред. и сост. Д. А. Керимов]. М.: Мысль, 
role in the society. According to the just statement of T. Lowy, the "state" has not disappeared and does not show any signs of extinction in the modern world, this institution has been preserved with many traditional functions inherent in it. In addition, according to T. Lowy, the lack of protection by the state endangers personal freedom ${ }^{4}$.

The first of the currently known scientific studies on the embodiment of individual orientations in the mass social trends that determine politics was made by Aristotle, who believed that the nature and method of government's management reflect the "virtues" inherent in the members of a given society. Herodotus and Thucydides, comparing the cultures of Greeks and Persians, as well as Athenians and Spartans, emphasized the specific features of the political systems of these peoples and associated them with the influence of the prevailing in these societies values.

In the XVIII century, the idea that governing forms reflect population's values was supported by Charles Louis Montesquieu, and almost a century later, by Alexis de Tocqueville, who investigated "the civil spirit of the American nation manifested in the activities of political institutions in the United States ${ }^{5}$.

Seymour Lipset was one of the first to address the political and cultural issues of democratization in the late 1950s. This American political sociologist emphasized the impossibility of isolating any key factor from the close interconnection of various aspects of economic development (industrialization, urbanization, wealth and education) ${ }^{6}$. He believed that genuine democratic modernization is manifested in the transformation of social conditions and the development of political culture. For example, "educating an employee provides the establishment of wide contacts with various social groups ... in connection with which employees are more susceptible to democratic values"7.

In the modern pioneering work, "Civil Culture: Political Attitudes and Democracy in Five Countries," Gabriel Almond and Sydney Verba concluded that the stability and vitality of the political regime depend on its perception by citizens as an "appropriate form of governing", as well as on the actual

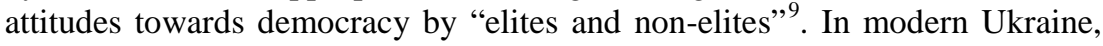
they stated that the slow formation of a democratic political culture at the institutional level is connected with the invariability of the political elite.

${ }^{4}$ Лоуи Т. Глобализация, государство, демократия: образ новой политической науки // Политические исследования. 1995. № 5. С. 108-119.

${ }^{5}$ Токвиль А. Демократия в Америке / Пер. с фр. - М.: Прогресс, 1992. 554 с.

${ }^{6}$ Lipset S.M. Political Man. The Social Bases of Politics. - NY.: Doubleday, 1960. 432 p.

${ }^{7}$ Lipset S.M. Some Social Requisites of Democracy: Economic Development and Political Legitimacy // American Political Science Review. 1959. № 53 (March). Pp. 69-195.

${ }^{8}$ Almond, Gabriel, Verba, Sidney. The Civic Culture: Political Attitudes and Democracy in Five Nations. - Princeton, 1963. 869 p.

${ }^{9}$ Barnes, S.H., Kaase, M. et al. Political Action: Mass Participation in Five Western Democracies. - Beverly Hills, CA: Sage,1979. 338 p. 
The unwillingness and inability of representatives of this elite to join the mechanism of interaction, the mood for conflicting forms of upholding their own political interests rather than reaching a political compromise, make the process of strengthening a democratic political regime and, accordingly, a democratic political culture, contradictory and inconsistent.

$\mathrm{R}$. Inglehart and $\mathrm{C}$. Weltzel demonstrate in detail the correlation between social and economic position (development) and commitment to the values of liberal democracy in the study, which, apparently, is the most authoritative and ambitious work of the last decade in the field of political culture. Scientists proceed from the provision that "the essential impact of modernization is not in the fact that democracy becomes acceptable to elites, but in the fact that the ability and desires of ordinary people to fight for democratic institutions increase" ${ }^{10}$.

The authors suggest that at the post-industrial stage of development, as a result of the growth of social and economic development, increased education, differentiation of the labor market and professions, the structure of the society is becoming more complex, where more and more creative, freethinking individuals are independent from the authorities: "Raising the level of education, expanding the need for obtaining information and the dissemination of knowledge by means of media helps people think more independently, reducing the restrictions on free choice" ${ }^{\prime 1}$. Naturally, with an increase in the total number of such individuals, the demand for civil rights and freedoms' realization increases. Thus, according to Welzel, "a person cannot be free without civil and political rights" 12 .

The emergence of an increasing number of informed and independentminded citizens, the formation of their associations, calls into question the legitimacy of authoritarian regimes that restrict citizens' political rights and freedoms. In such circumstances, the existence of authoritarianism becomes unacceptable for at least two reasons: firstly, "effective management becomes more expensive and restricting the institutional choices of elites"13, and secondly, "as a rule, authoritarian elites have enough power to suppress civil requirements, as long as they control the troops and are ready to use force. However, the resources that become a civil capital, and the determination with which citizens direct them to fight for freedom, can eliminate the power of

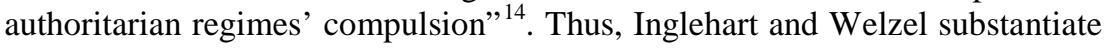

\footnotetext{
Pp. 126-140.

${ }^{10}$ Welzel, Christian and Inglehart, Ronald. Journal of Democracy, no. 19 (2008).

${ }^{11}$ Inglehart, Ronald and Welzel, Christian. Modernization, Cultural Change and Democracy: The Human Development Sequence. - Cambridge, 2005. 344 p.

${ }^{12}$ Welzel, Christisn. European Journal of Political Research, no. 45 (2006). Pp. 871-896.

${ }^{13}$ Ibid. Pp. 871-896.

${ }^{14}$ Inglehart, Ronald and Welzel, Christian. Modernization, Cultural Change and Democracy: The Human Development Sequence. - Cambridge, 2005. 344 p.
} 
the crucial role of ordinary citizens in the process of democratization and draw the mechanism of democratic attitudes' emergence at the micro level under the influence of modernization, which by means of implementing the request for political rights and freedom, are transformed into democratic institutions at the macro level.

So the key thesis underlying the study of political culture is the existence of a stable relationship between the value orientations of individuals and the nature of the political regime and stable functioning of institutions and the system as a whole.

With regard to the people power, this means that dominance of the democratic values of freedom, independent choice, etc. in the mass consciousness (that is, the opinion that the majority of the members of a given society share) determines the establishment, preservation and development of effective democratic institutions.

In the paradigm of the political culture study, effective democracy appears to be a mechanism for the institutionalization of civil rights and political freedoms which guarantees the possibility of independent choice in the private, public and state spheres. Obviously, a democratic order is not supported and maintained by any choice of citizens. The story contains quite a few illustrations of the crushing blows inflicted by the demos in the course of democratic procedures concerning people power. One of the most striking cases of the history of the XX century is the legal transfer of power to the Nazis in Germany and the ensuing rollback to fascist totalitarianism. Therefore, civil choice, which is motivated by the desire for freedom and independence, is crucial for democracy. So, the stability of the system and the regime depends on the mutual conformity of values and institutions. It follows from this that democracy successfully develops in societies whose members possess civil qualities and strive for freedom and independence. Even if authoritarian or totalitarian groups come to power in such societies, then, as the political history of the countries of Central and Eastern Europe shows, the pressure of social forces will not allow them to rule as long as they would like to. As Pamela Paxton maintains, the costs of tyrannical regimes to pacify the dissatisfied people increase under the influence of citizens seeking freedom and with the strengthening of antigovernment movements which decreases the effectiveness of autocratic systems, creates conflicts within the ruling class (between conservatives and reformers) and ultimately leads to a collapse of autocracies ${ }^{15}$.

It is important to emphasize here that we are talking about the processes taking place precisely in post-industrial countries. The transition to postindustrialism, which began around 1970, led to changes in the values of mass consciousness, which also influenced the nature of the democratic process and

\footnotetext{
${ }^{15}$ Paxton, Pamela. American Sociological Review, no. 67 (2002): 254-277.
} 
the perception of the very concept of democracy in developed countries. In this regard, a number of researchers have announced a "crisis" of liberal democracy in the West. The analysis of the theme of the "crisis" of liberal democracy reveals new patterns of realizing the values of democracy in modern postindustrial societies and compares them with those inherent in transitional societies. Therefore, it is worth considering this issue more closely.

Crozier was one of the first to write about the "crisis" in 1975. Putnam, together with Christine Goss, supported this statement in the early 2000s: "It's paradoxical, but during the grand triumph of liberal democracy, there are also some concerns about the effectiveness of the most important social institutions, including the institutions of representative power, in developed democracies" 16 .

Although Putnam and other equally authoritative authors substantiate political passivity observed in post-industrial societies as being a result of reduced "social capital", however, Inglehart and Welzel offer a different solution. These authors change their perspectives and it becomes clear that, in fact, there is not one, but two trends. "On the one hand, bureaucratic and elite-driven forms of people's participation in the political process, such as voting and party membership, are indeed declining. On the other hand, the volume of anti-elite forms of such participation, driven by expressive intrinsic motivation, has expanded dramatically" ${ }^{17}$.

Ulrich Beck explains the ongoing changes as a consequence of the diversification of relations between people conditioned by socio-economic development, abandoning the traditional ties and gaining the freedom to choose new social roles and creating social ties based not on coercion or necessity. According to him, in post-industrial democratic societies there is a transition from "forced kinship" to "sympathy according to one's choice"18.

Thus, social capital does not disappear, it updates its character and forms of manifestation, taking into account the changes in the social formation (from industrial to postindustrial). Today, members of postindustrial societies are less likely to join hierarchical-type political organizations and are more critical of state policy and bureaucracy, which is reflected, for example, in a decrease in voters' turnout for elections. On the contrary, people are increasingly participating in new forms of expressing interests: in single pickets, boycotts, signing petitions on the Internet, demonstrations organized through social networks, etc.

${ }^{16}$ Putnam, Robert and Goss, Kristine. Introduction. Democracies in Flux: The Evolution of Social Capital in Contemporary Society. - Oxford, 2002. 528 p.

${ }^{17}$ Инглхарт Р., Вельцель К. Модернизация, культурные изменения и демократия / Пер. с англ. - М.: Новое издательство, 2011. 464 с.

${ }^{18}$ Beck, Ulrich. Losing the Traditional: Individualization and «Precarious Freedoms». Individualization. London, 2002. Pp. 1-21. 
New forms of political participation were called "unorthodox", in contrast to the "traditional" ones (voting, voters' appeals to deputies, etc.). Back in the late 1970s, Barnes, Kaase, and their co-authors, exploring the protest potential, developed methods for measuring "traditional" and "unorthodox forms of participating in political activity", calling the latter "a stable characteristic of the general public in democratic countries"19.

The most significant contribution to understanding the process of the democratic values formation among citizens of a given society was made by the authors which can conditionally be divided into two main groups: institutionalists and communitarians.

Robert Jackman, Dunkwart Rastow, Ross Miller, Edward Muller, Mitchell Seligsen, Guillermo O'Donnell and Phillipp Schmitter believe that democratic values are formed in the population during the long-term and effective functioning of democratic institutions in the course of habituation or "institutional learning" ${ }^{20}$, thanks to the adoption of norms and the realization of the value of democracy. At the same time, economic development plays a supporting role, also contributing to the spread and strengthening of the values of democracy in the mass consciousness. An additional factor in strengthening democracy (in the context of existing democratic institutions) is economic growth. Such logic leads to the conclusion that it is impossible to create a culture that supports democracy under authoritarianism or totalitarianism. However, political history provides a lot of examples of the opposite. In modern times, the most striking illustration is the democratization of the USSR and the countries of the Soviet Union. In addition, the practice of the CIS and other countries shows that to establish democratic values in a society, it is not enough to adopt a democratic constitution and build institutions of representation and public control. Something else is needed.

Supporters of elitist conceptions write about the decisive role of the political elite in building and maintaining the stability of the institutional foundation of democracy. For example, Valerie Buns: "If political leaders are considered to be the founders of democracy ... then in the future, after the initial breakthrough, it is also them whom will determine whether it will be preserved or undermined" ${ }^{21}$. In this discussion, the following situation can be observed: the ruling class is in no way dependent on society, and citizens are just passive observers who are not able to influence politics. But here we are no longer talking about a democratic regime, because the interests of the demos are not taken into account in any way, which destroys the very essence of democracy.

${ }^{19}$ Barnes, S.H., Kaase, M. et al. Political Action: Mass Participation in Five Western Democracies. - Beverly Hills, CA: Sage,1979. 338 p.

${ }^{20}$ Rastow, Dankwart. Polis [Political studies], no. 5 (1996): Pp. 5-15.

${ }^{21}$ Bunce, Valerie. Comparative Political Studies, no. 33 (2000): Pp. 703-734. 
Therefore, we should not forget about the important role of social movements and the values shared by them, or, generally speaking, social forces that resist the pressure of the central government and want independence. In turn, these social forces were able to become influential actors due to an increase in their economic capital (as well as cognitive and social). Guillermo O'Donnell and Phillipp Schmitter argue that the main impetus for democratization is provided by the change-oriented and reform-minded elites who direct social forces and manage their collective actions to overcome the resistance of the conservative-minded part of the ruling class and renew the political system $^{22}$. The role of the social movement here is much more modest - only the execution of the political modernization program developed by a narrow group of elites. Further stability of democracy, according to Juan Linz and Alfred Stepan, depends on the degree of elite's agreement that democracy is the "only possible option" of political life ${ }^{23}$.

It is difficult to overestimate the role of the elite in democratization, especially in terms of building democratic institutions and supporting their working condition. In addition, it is difficult to imagine that even the most skillful actions of a small group of elite will help establish a stable democratic regime if there is no widespread support of the population.

Ferdinand Tönnis to analyze the collectivism (as the basis for theoretical models of democracy), distinguished between community and society. In his opinion, the community is firmly held together by uniform ties, providing a high level of cohesion, giving the group closeness and generating a collective identity.

Society, according to F. Tennis, is an open-ended group uniting individuals from different layers on the basis of similarity of interests and is a source of individualistic identification. Daphne Oiserman, Heather Kuhn, and Marcus Kemmelmeyer consider intra-group relationships and mutual obligations as the most essential characteristics of collectivism, which they call "interdependent" self-awareness.

In addition, the personal freedom of a team, collective member is limited not only by external obligations, it is also constrained by the internal suppression of individual needs that run counter to social ones, as well as by the need to constantly adapt to the interests of the group, because there is no other choice.

So, collectivism is not a specific integral feature of any culture. The explanation of collectivism as a way of protecting a group in the face of danger suggests that in any society in a critical situation, the collectivist values

${ }^{22}$ O’Donnell, Guillermo, Schmitter, Philipp. C. Tentative Conclusions about Uncertain Democracies. Transitions from Authoritarian Rule. Baltimore, 1986. Vol. 4. Pp. 1-78.

${ }^{23}$ Linz, Juan, Stepan, Alfred. Problems of Democratic Transition and Consolidation: Southern Europe, South America and Post-Communist Europe. - Baltimore, 1996. 504 p. 
of group discipline, a unified norm, powerful state power, with the help of which overall vitality is most effectively achieved, prevail in the mass consciousness.

\section{National and political activity as an important mechanism for developing a democratic political culture}

Ukrainian nation is now in a situation where both the process of civil society development and the process of transformation of national consciousness take place, which determines the specifics of moral and ethical values' formation. Although these two processes are equal in importance, the system of moral and ethical values of civil society originates from national foundations and traditions, yet the general foundations for the development of civil society are much broader than the national foundations for functioning and transformation of national borders and statuses. National traits in one way or another influence the processes that promote or impede the development of civil society.

The process of building a nation takes on the character of political certainty with the proclamation of Ukraine as a democratic state, thus, such a society is formally formed on an appropriate national basis. This process is characterized by the will of citizens and the level of freedom of choice in determining national and civil priorities when choosing a language of communication, the values of state symbols, and it is also necessary to take into account the specific features of social institutions' functioning.

Civil society in the world has become an objective condition for the existence of a nation in democratic states, and yet, this does not mean that the features of its formation and functioning are the same for all countries and world communities. All these communities are united by the fact that the foundations of the civil society development are formed by the global conditions for the functioning of social relations that correspond to a particular historical era.

The twentieth century is also the bearer of the corresponding traits that became the basis for the formation of the nation and the mechanisms of the civil society development. Thus, considering civil society as a social phenomenon that accumulates certain mechanisms leading to changes in the society, and to a greater extent to changes in consciousness, it is necessary to take into account the national characteristics of the social system development. It is also important to take into consideration the specifics of the historical features of the nation formation in order to determine the directions of the civil society development in any state, that is why we focus on the study of the mechanisms of formation and further civil society development based on the national mentality of the Ukrainian people. And the success of this process will depend on the level of political culture in the society. 
As the experience of Ukraine's development in recent decades has shown, it can be concluded that gradual and spontaneous changes in the consciousness and morals of citizens are an invariable condition for progressive transformations, and, of course, not without the state's influence through education and upbringing. Such influence should not be carried out as a party propaganda or ideology, but as an independent and important direction in public policy.

The formation of civil society is influenced by individual conditions that determine the national specifics of its development. Thus, civil society is a form of social activity organization which is formed on a certain basis including the joint territorial location of the national community, the language of communication, the specifics of economic development and political governance.

The mechanisms of formation and development of democratization (civil society) in modern Ukraine are the national mentality, national and political activity, which contribute to the development and raising of the level of democratic political culture.

In scientific studies on the process of the civil society development, various factors are distinguished: social responsibility, elections, independence of self-government, media responsibility, civil control, and others. However, the role of the national mentality of Ukrainian nation in this process has not been fully studied yet.

The national mentality enshrines social and national symbols that preserve and convey the history of the will of the Ukrainian people. It is very important to take into account the fact that people defended their own national interests in unfavorable conditions, and many of them were not realized. And this fact it is vital to take into account this fact because unrealized dreams of freedom and national images form an obstacle in the subconscious in the form of fear that subsequent attempts will also result in defeat or punishment. In addition, state dictatorship and monopoly control over the activities of various social institutions became a prerequisite for the cessation of their activities and absence of any initiative on the part of an individual.

Thus, objective conditions have formed in the national mentality of the Ukrainian nation the idea that public organizations can maintain independence and the right to autonomy from the invasion of state institutions only when there is the state's permission for that, or if they are economically protected, which allows them to exercise legal regulation of relationships with state institutions limiting their intervention.

A nation is also formed on the basis of the joint interaction of different ethnic groups that historically live on a particular territory. It is the basis of agreement of all representatives of ethnic groups, the joint experience of managing and a single will to unite around a priority ethnic group where a 
nation can be formed, and the role of the state in this case is to provide legal support for such coexistence. "No one will build a state for us unless we build it ourselves, and none of us will make a nation if we do not want to be a nation ourselves" 24 .

The national mentality is formed based on the joint experience of coexistence and cultural traditions in different areas of public life: economic, political and cultural.

National and political activity as a mechanism of social maturity of a society is structured in a certain way, it is realized through behavior, motives, desires, interests of different social groups which are united in a nation. Thus, political culture acts as a consolidating factor in the formation of a democratic state.

Thus, there is a close relationship between political culture, economic development and stable democracy. "Values and social relationships are interconnected and mutually developing." The effective work of institutions is associated with "civil virtue": "a republic grows a virtuous individual, and a virtuous individual creates a republic. Views and practice constitute a mutually developing balance. The effectiveness of institutions and their attention to the needs of the population depends on "republican virtues" and practice. Social environment and history deeply affect the performance of institutions. If the regional foundation is favorable, the regions have support from regional traditions, but when this foundation is scarce, new institutions are ineffective $" 25$.

Thus, the formation of the political culture of the new - democratic type - will depend on many factors and, above all, on the pace of development of national political elite's and each individual's self-awareness, on their social protection and real, not declared, rights and freedoms, as it should be in any civil society.

\section{CONCLUSIONS}

Democratic transformations in European states, including Ukraine, marked the beginning of a new stage in the processes of democratization, the third one in the world political history. One of the factors that can directly contribute to or impede democratic political development is political culture. In the paradigm of the study of political culture, effective democracy appears to be a mechanism for the institutionalization of civil rights and political freedoms, and guarantees the possibility of independent choice in the private, public and state spheres. The stability of the system and the regime depends

${ }^{24}$ Липинський В. Листи до братів-хліборобів. Про ідею і організацію українського монархізму. - Відень, 1926. - С. 15.

${ }^{25}$ Патнам Р. Д. Творення демократії: Традиції громадянської активності в сучасній Італії / Р. Д. Патнам, Р. Леонарді, Р. Й. Нанетті ; пер. $з$ англ. В. Ющенко. - К. : Вид-во Соломії Павличко «Основи», 2001. - 302 с. 
also on the mutual conformity of values and state institutions. The mechanisms of formation and development of democratization (civil society) in modern Ukraine are the national mentality, national and political activity which contribute to the development, raising of the level of democratic political culture.

National and political activity as a mechanism of society's social maturity is realized through behavior, motives, desires, interests of different social groups which are united in a nation. The formation of political culture of a democratic type depends on many factors and, above all, on the pace of development of the political elite's and each individual's national selfawareness, their social security and the realization of rights and freedoms. State policy in this direction should be focused, stable, based on the principles of high morality, justice and law.

\section{SUMMARY}

Ukrainian society, like other post-communist states of Central and Eastern Europe, is at the epicenter of global transformational dynamics. The democratic transformations in these countries marked the beginning of a new stage in the processes of democratization, the third one in the world political history. One of the factors that can directly contribute to or impede democratic political development is political culture.

Despite the existence of different points of view regarding the essence of the state prevailing in various historical periods, the recognition of the role of the main political institution has remained unchanged. In the scientific studies of various authors, we see the embodiment of individual orientations in mass social trends that determine politics, specific features of political systems, linking them with the influence of the values prevailing in these societies. Thus, the key thesis underlying the study of political culture is the presence of a stable relationship between individuals' value orientations and the nature of the political regime, the stable functioning of institutions and the system as a whole. With regard to democracy, this means that dominance of the democratic values of freedom, independent choice, etc. in the mass consciousness (which is shared by the majority of the members of a given society) determines the establishment, preservation and development of effective democratic institutions.

The Ukrainian nation is now in a situation where both the process of civil society development and the process of transformation of national consciousness take place, which determines the specifics of moral and ethical values' formation. The system of moral and ethical values of civil society, first of all, originates from national foundations and traditions. The mechanisms of forming and developing civil society in modern Ukraine are the national mentality, national and political activity which contribute to the development, raising of the level of democratic political culture. 
In scientific studies on the process of the civil society development, various factors are distinguished: social responsibility, elections, independence of self-government, media responsibility, civil control, and others. However, the role of the national mentality of Ukrainian nation in this process has not been fully studied yet.

The national mentality enshrines social and national symbols that preserve and convey the history of the will of the Ukrainian people. National mentality is formed based on the joint experience of coexistence and cultural traditions in different areas of public life: economic, political and cultural. National and political activity as a mechanism of society's social maturity is structured in a certain way, it is realized through behavior, motives, desires, interests of different social groups which are united in a nation. An indicator of the social maturity in modern Ukraine is its own model of democratic political culture. Thus, political culture acts as a consolidating factor in the formation of a democratic state, civil society and a factor of political progress. Thus, the state policy in this direction should be focused, stable, based on the principles of high morality, justice and law.

\section{REFERENCES}

1. Аристотель. Сочинения: В 4 т. Т. 4 / [пер. с древнегреч.; общ. ред. А. И. Доватура]. М.: Мысль, 1983. С. 376-644.

2. Аквинский Ф. Сочинения / [пер. А. Апполонова]. М.: Ленанд, 2015. $242 \mathrm{c}$.

3. Гегель Г. Философия права: Пер. с нем. / [ред. и сост. Д. А. Керимов]. М.: Мысль, 1990. 524 с.

4. Лоуи Т. Глобализация, государство, демократия: образ новой политической науки // Политические исследования. 1995. № 5. С. 108-119.

5. Токвиль А. Демократия в Америке / пер.с фр. - М.: Прогресс, 1992. $-554 \mathrm{c}$.

6. Lipset S.M. Political Man. The Social Bases of Politics. - NY.: Doubleday, 1960. 432 p.

7. Lipset S.M. Some Social Requisites of Democracy: Economic Development and Political Legitimacy // American Political Science Review. 1959. № 53 (March). Pp. 69-195.

8. Almond, Gabriel, Verba, Sidney. The Civic Culture: Political Attitudes and Democracy in Five Nations. - Princeton, 1963. 869p.

9. Barnes, S.H., Kaase, M. et al. Political Action: Mass Participation in Five Western Democracies. - Beverly Hills, CA: Sage, 1979. 338 p.

10. Welzel, Christian and Inglehart, Ronald. Journal of Democracy, no. 19 (2008). Pp. 126-140.

11. Inglehart, Ronald and Welzel, Christian. Modernization, Cultural Change and Democracy: The Human Development Sequence. - Cambridge, 2005. 344 p. 
12. Welzel, Christisn. European Journal of Political Research, no. 45 (2006). Pp. 871-896.

13. Welzel, Christisn. European Journal of Political Research, no. 45 (2006): 871-896.

14. Inglehart, Ronald and Welzel, Christian. Modernization, Cultural Change and Democracy: The Human Development Sequence. - Cambridge, 2005. 344 p.

15. Paxton, Pamela. American Sociological Review, no. 67 (2002): 254-277.

16. Putnam, Robert and Goss, Kristine. Introduction. Democracies in Flux: The Evolution of Social Capital in Contemporary Society. - Oxford, 2002. 528 p.

17. Инглхарт Р., Вельцель К. Модернизация, культурные изменения и демократия / Пер. с англ. - М.: Новое издательство, 2011. 464 с.

18. Beck, Ulrich. Losing the Traditional: Individualization and «Precarious Freedoms». Individualization. London, 2002. Pp. 1-21.

19. Barnes, S.H., Kaase, M. et al. Political Action: Mass Participation in Five Western Democracies. - Beverly Hills, CA: Sage,1979. 338 p.

20. Rastow, Dankwart. Polis [Political studies], no. 5 (1996): Pp. 5-15.

21. Bunce, Valerie. Comparative Political Studies, no. 33 (2000): Pp. 703-734.

22. O’Donnell, Guillermo, Schmitter, Philipp. C. Tentative Conclusions about Uncertain Democracies. Transitions from Authoritarian Rule. Baltimore, 1986. Vol. 4. Pp. 1-78.

23. Linz, Juan, Stepan, Alfred. Problems of Democratic Transition and Consolidation: Southern Europe, South America and Post-Communist Europe. - Baltimore, 1996. 504 p.

24. Липинський В. Листи до братів-хліборобів. Про ідею i організацію українського монархізму. - Відень, 1926. - С.15.

25. Патнам Р. Д. Творення демократії: Традиції громадянської активності в сучасній Італії / Р. Д. Патнам, Р. Леонарді, Р. Й. Нанетті ; пер. 3 англ. В. Ющенко. - К. : Вид-во Соломії Павличко «Основи», 2001. $-302 \mathrm{c}$.

\section{Information about the author:} Baklanova N. M.,

Candidate of Political Sciences, Associate Professor at the Department of World History and Methodology of Science, South Ukrainian National Pedagogical University named after K. D. Ushynsky 26, Starofrankivska str., Odessa, 65020, Ukraine 